\title{
The relationship between the performance of soil conditions and damage following an earthquake: a case study in Istanbul, Turkey
}

\author{
G. Ç. İnce \\ Division of Civil Engineering, Department of Geotechnical Engineering, Faculty of Engineering, Aksaray University, \\ 68100 Aksaray, Turkey
}

Received: 14 March 2011 - Revised: 2 May 2011 - Accepted: 2 May 2011 - Published: 21 June 2011

\begin{abstract}
Istanbul city has experienced many strong earthquakes throughout its history and suffered extensive damage. The old Istanbul (Fatih and Eminonu districts), one of the most densely populated locations of Istanbul city, is a commercial centre and has many significant historical buildings. In this study, the data pertaining to the damage sustained by historical artifacts and structures from past earthquakes, are examined along with the soil amplification of the region, the liquefaction and slope stability risk in relation to the seismic microzonation maps which were prepared using geographic information system techniques. The relationship between soil behaviour and the damage resulting from previous earthquakes. The structural damage observed in the region was in accordance with the microzonation maps. Since the area does not have a high risk in terms of slope stability, this does not have much impact on the level of damage. However, it was found that soil amplification and partial liquefaction contributed to the damage to historical artifacts and structures.
\end{abstract}

\section{Introduction}

It is known that the extent of the damage to buildings caused by earthquakes is related to local soil conditions. Therefore, in the ground surveys performed before the construction of a building, it is necessary to examine how the layers, which constitute the ground under and around the proposed building, would behave during an earthquake.

If the structural damage during an earthquake is the result of complete ground subsidence that leads to large scale displacement, the relationship between the structural damage and local soil conditions can obviously be seen. For example, loose-grained ground may cause total and differ-

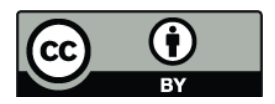

Correspondence to: G. Ç. İnce (gokcecicekince@gmail.com) ential settlements from squeezing due to tremors and result in major structural damage to buildings. It has been observed that during earthquakes the dynamic stresses and pore water pressures on soft clay and sand layers cause massive landslides. In general, the soil conditions which contribute to the damage caused by earthquakes are; soil amplification, soil liquefaction, landslides and ground settlement.

In this study, the possible changes (in terms of soil amplification, soil liquefaction, slope stability) that can occur following an earthquake were analysed in a selected study area and the results presented with micro-zoning maps. By successively running comparisons on the damage information on historical monuments located in the study area with ground micro-zoning maps, the impact of the ground changes on the damage to historical monuments were investigated and analysed.

The study was undertaken in the district of Fatih and Eminonu, Istanbul, Turkey as shown in Fig. 1. This area is also known as the historical peninsula. Istanbul has experienced many strong earthquakes in its history and suffered extensive damage. The district of Fatih and Eminonu is one of the most densely populated locations of Istanbul city. It is a commercial centre and has many significant historical buildings. In this study, we examined the data pertaining to the damage sustained by historical artifacts and structures from past earthquakes, the soil amplification of the region, assessed the liquefaction and slope stability risk in relation to the seismic microzonation maps and investigated the relationship between soil behaviour and damage resulting from previous earthquakes.

Although geological structure is important, local soil conditions are known to have a great influence on the potential damage resulting from earthquakes (Seed and Idriss, 1969; Seed et al., 1972; Chang and Chang, 1994). Since the response of soils under dynamic and static loading is different from other civil engineering materials and their geotechnical properties tend to change locally from one point to another,

Published by Copernicus Publications on behalf of the European Geosciences Union. 


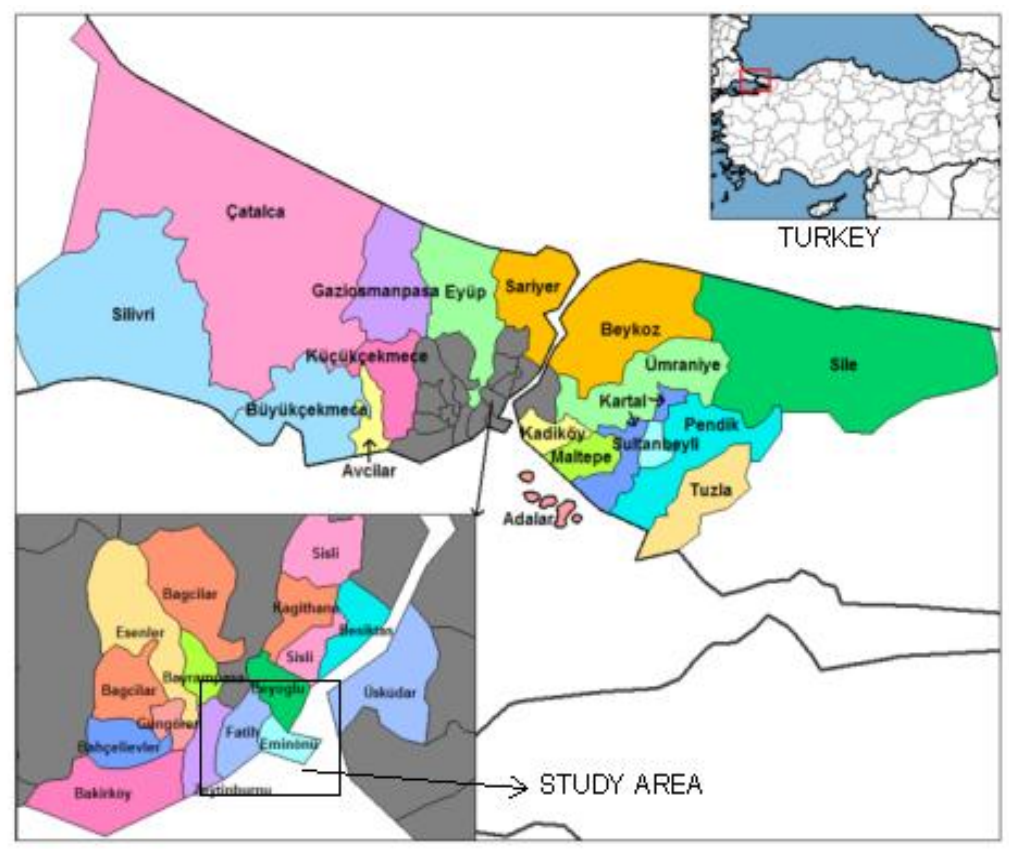

Fig. 1. Location of the study area.

there is a need to evaluate the regions with respect to the suitability for settlement and to determine the effects of future earthquakes on existing residential areas.

Seismic microzonation studies are considered to be an efficient tool for the assessment of seismic hazard in urban areas in terms of the assessment of soil amplification, risks of liquefaction potential, slope failure and differential settlements. Seismic microzonation studies generally involve the following three stages: assessment of seismicity and regional seismic hazard, identification of geological structure and fault features and the determination of the effects of local geotechnical conditions in the region. The local geotechnical effects are evaluated with respect to soil amplification, slope stability and liquefaction potential. The seismic hazard of the Fatih and Eminonu districts study area was assessed with respect to the probability of it exceeding $10 \%$ in $50 \mathrm{yr}$ with a probabilistic approach at $250 \mathrm{~m}$ intervals utilizing the studies performed within the scope of the Global Seismic Hazard Assessment Program (GSHAP, 1999) project and the SEISRISK III computer programme (Bender and Perkins, 1987).

For microzonation studies to be successful, the geological and fault structure of the region should be correctly evaluated. Therefore, geological maps of the study area, including fault systems and geological cross sections, were prepared in detail utilizing the data from 125 borings, surface geology observations and topographical information. The study area was divided into $250 \mathrm{~m} \times 250 \mathrm{~m}$ cells and representative soil profiles were created for each cell compatible with the geological maps and cross sections.
The site response analysis under earthquake loadings was performed using the Equivalent-Linear Earthquake Site Response Analysis Programme (EERA) developed by Bardet et al. (2000) which is based on the propagation of waves in a viscous elastic half space. For the simulation of earthquake motion, the Target Acceleration Response Spectra Compatible Time Histories (TARSCTHS) computer programme (Papageorgiou et al., 2000) was used. This programme is capable of producing spectrum compatible earthquake time histories. As a result of the dynamic site response analysis, the spectral accelerations, spectral velocities and amplifications were computed. Additional soil amplification values were determined for each cell based on equivalent shear wave velocity using the empirical relationship proposed by (Midorikawa, 1987).

In the preparation of microzonation maps, with respect to soil amplification, the procedure recommended in the manual Microzonation for Earthquake Risk Mitigation, (MERM, 2003) prepared by World İnstitute for Disaster Risk Management (DRM) was used. DRM is a network for applied research, implementation and dissemination in the field of disaster risk management. The Fatih and Eminonu districts study area was mapped as $A_{\mathrm{GS}}, B_{\mathrm{GS}}$ and $C_{\mathrm{GS}}$ in descending order of seismic shaking intensity with respect to an earthquake event corresponding to probability of exceedance of $10 \%$ in $50 \mathrm{yr}$.

In order to evaluate the study area in terms of seismic slope stability hazard, the KoeriSlope V1.0 programme (Fahjan et al., 2003), based on the slope stability analysis method proposed by Siyahi and Ansal (1993), was used and the 
Table 1. Disastrous earthquakes around Istanbul from 325 to 1894 (Istanbul Earthquake Symposium, 1991).

\begin{tabular}{cc}
\hline Date & MSK \\
\hline 325 & IX \\
427 & IX \\
478 & IX \\
553 & X \\
865 & IX \\
986 & IX \\
1344 & IX \\
1462 & IX \\
1509 & IX \\
1659 & IX \\
1766 & IX \\
1894 & X \\
\hline
\end{tabular}

microzonation map was prepared in accordance with the computed factor of safety values.

The microzonation map regarding the liquefaction potential was based on the assessment of liquefaction potential according to the simplified procedure recommended by Seed et al. $(1984,1985)$ for the coast lines of the Golden Horn, Yenikap and Kumkap and along Vatan street (see Fig. 6) where liquefaction is thought likely to occur due to the characteristics of the soil layers.

\subsection{Historical earthquakes in Istanbul}

The 12 massive earthquakes that have affected the city of Istanbul between in the period 325 to 1894 are given with the year and intensity in Table 1 . The shortest time interval between two earthquakes was $47 \mathrm{yr}$ and the longest interval was $358 \mathrm{yr}$ and the average time interval between two earthquakes is $143 \mathrm{yr}$. The most significant earthquakes are those that occurred in 1509,1766 , and 1894 . The 1509 earthquake is remembered as the "small doomsday" since its epicentre was close to Istanbul where significant damage was caused.

A further study was undertaken by Barka (1991) of the earthquakes that occurred in the Marmara region. Figure 2 shows the distribution of earthquakes in the Marmara region from 1719 to 1999. In this figure, source areas for each individual earthquake are schematically shown as gray-shaded ellipses based on the maximum damage area and the presentday understanding of the fault segments along the NAFZ.

In 1766, a major earthquake affected historical records. these records state that the earthquake extended from İzmit to Gelibolu and broke the Marmara fault line. There was a tsunamis and great damage to the historical buildings including mosques and the Topkapi Palace. The documentation concerning the 1894 reports that the macro seismic epicentre was 40.8 north latitude and 29.0 east longitude and the largest intensity was X (Gündoğdu et al., 1991). However,

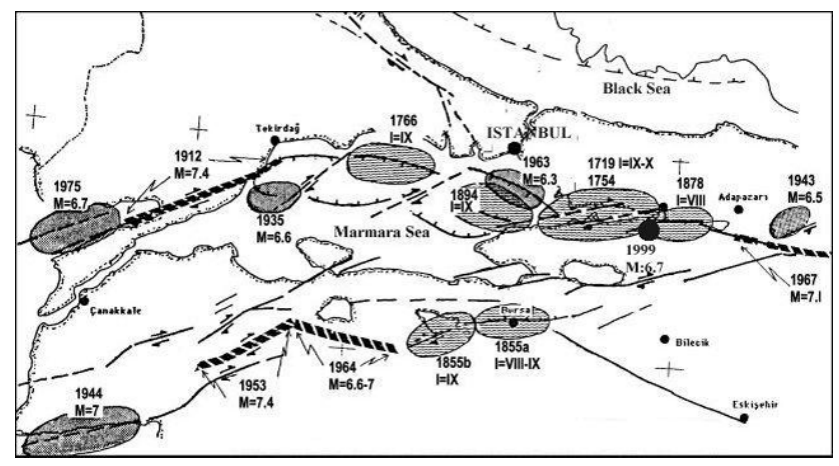

Fig. 2. Historical Earthquake Map of the Marmara Region (Barka, 1991).

other authors (Eginitis, 1894; Öztin and Bayülke, 1990) state that the highest intensity was VIII. After this earthquake, the director of the Athens Observatory, Dr. Eginitis was invited by Abdulhamit the sultan at that time) to undertake research about the earthquake and Eginitis prepared an iso intensity map from the data obtained. Figure 3 presents the map prepared by Eginitis. Figures 4 and 5 show the damage caused by this earthquake.

Most of the damage caused by the 1894 earthquake is observed on the edges of Fatih and Beyazit districts of Istanbul (Barka, 1991) with subsidence occurring in the filling materials in Eminönü (Eginitis, 1894). Öztin and Bayülke (1990) reported that the Kapalıçarşı (Grand Bazaar) in Eminonu was significantly damaged as a result of this subsidence and 135 of the total 280 deaths from this earthquake were caused by the collapse of the Kapalıçarşı. Thus, it can be seen that earthquakes present a significant risk to historical artifacts and structures in Istanbul, particularly in the historical peninsula in which the Eminonu district is located.

\section{Geology of the historical peninsula}

The geology and soil profile of the historical peninsula have been investigated through surface geological investigations. 125 borings have been drilled for various purposes and several trial pits for further investigation have been opened by Istanbul Metropolitan Municipality, Fatih and Eminönü Municipality, General Directorate for State Hydraulic Works and JICA in and around the peninsula. The study area was divided into $250 \mathrm{~m} \times 250 \mathrm{~m}$ cells (U12, K14, etc.) and representative soil profiles were created for each cell compatible with the geological maps and cross sections. The studies showed that two distinct formations outcrop on the peninsula (Fig. 6). The older one comprising the bedrock in the area is known as the Trakya formation, it is Lower Carboniferous and represented by interbedded claystone, siltstone and sandstone (graywacke) (Kaya, 1971; Vardar and Bayraktar, 1993). The other formation, unconformably overlying the Trakya formation, is a continuous sequence of 


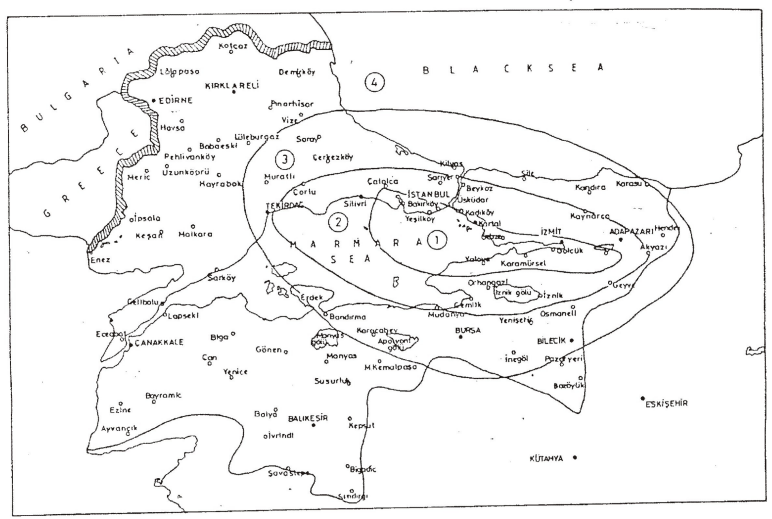

Fig. 3. The iso intensity curves of the 1894 earthquake in the Marmara Region (Eginitis, 1895).

deposits from the Upper Oligocene to the Upper Miocene, composed of loosely cemented and interbedded sand and clay with increased carbonate content in the upper levels resulting in intercalations of limestone and marl. This is a depositional sequence that continued uninterrupted until the end of the Miocene period (Yıldırım and Savaşkan, 2002, 2003). The sequence, which has been described as a series of formations called "Gürpınar", "Çukurçeşme", "Güngören" and "Bakırköy" in the literature (Sayar, 1976), starts with widespread sand and gravel layers and continues with overconsolidated green clay layers. The clays, interbedded with sands, continued intense deposition throughout Sarmatian and, in the upper levels, due to increased carbonate content in lacustrine environment, became interbedded with marl and argillaceous limestone (Figs. 6 and 7). The uppermost level of the sequence is represented by carbonaceous clay or sand layers of the Upper Miocene (Pontian) (Baykal, 1974; Yıldırım and Savaşkan, 2003).

Grayish brown graywackes belonging to the Trakya formation outcrop near Aksaray, between Kumkapı and Sarayburnu, and on the steep slopes descending towards the Golden Horn are characterised by normal faults striking northwest-southeast and northeast-southwest. This sequence, consisting of sandstone, siltstone and claystone layers with lenses of gray limestone, dips westward, and is unconformably overlaid by Upper Oligocene - Upper Miocene deposits, which increase in thickness as they extend towards the west. The Kirklareli formation of Middle Eocene Lower Oligocene, which does not outcrop in the historical peninsula, has been encountered in some deep water wells in the southwest corner of the peninsula, at the location where the historical city walls reach the Marmara Sea, near Yedikule. The relevant borehole records indicate a 5-15 m thick clayey and sandy basal layer followed by marl and limestone belonging to the Kurklareli formation. The location is significant in that it is the easternmost point where the Kırklareli formation has ever been encountered.

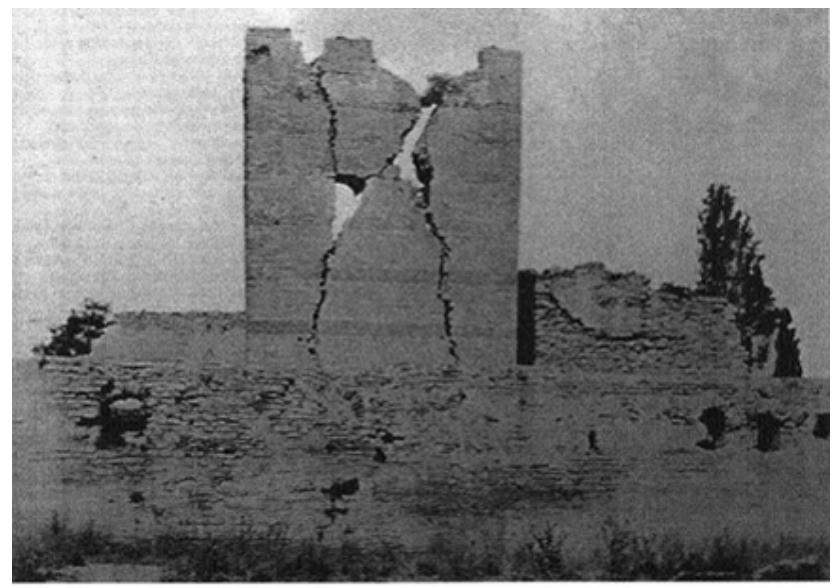

Fig. 4. A photograph of the damage to the towers in Topkapi following the 1894 earthquake in Istanbul (http://www.tarihimiz.net/v3/haberler/genel/tarihte-istanbuldepremleri.html).

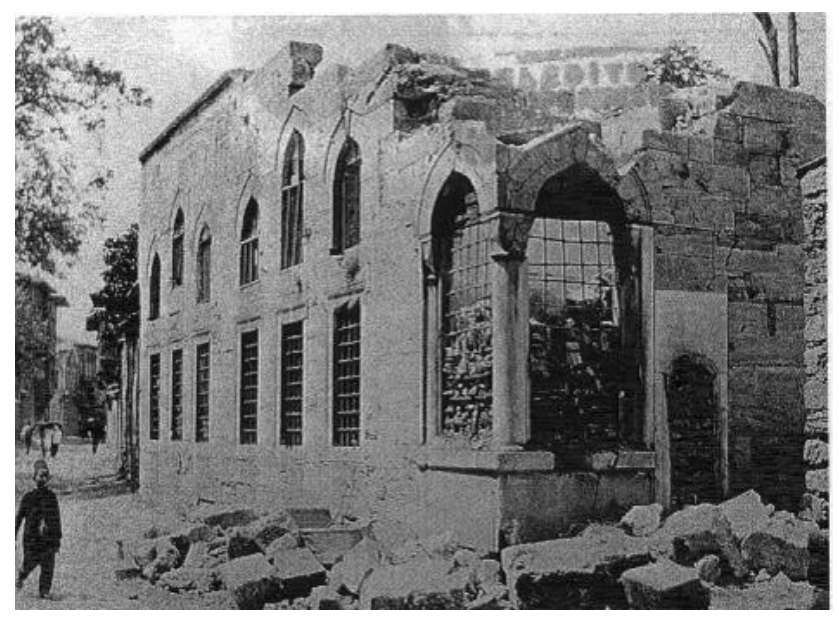

Fig. 5. Another example of damage caused by the 1894 earthquake in Istanbul (http://www.tarihimiz.net/v3/haberler/genel/ tarihte-istanbul-depremleri.html).

\section{Amplification properties of the local ground conditions}

\subsection{Site response analysis}

The behaviour of soil layers in the study area under earthquake effects is investigated by the EERA programme (Bardet et al., 2000) prepared in Excel routines and based on the equivalent linear analysis programme SHAKE (Schnabel et al., 1972) which is widely used in geotechnical earthquake engineering. The nonlinear behaviour of the soil layers are approximately represented with a damped linear elastic model and equivalent linear analysis. The stress-strain properties of the soils are defined taking into consideration 


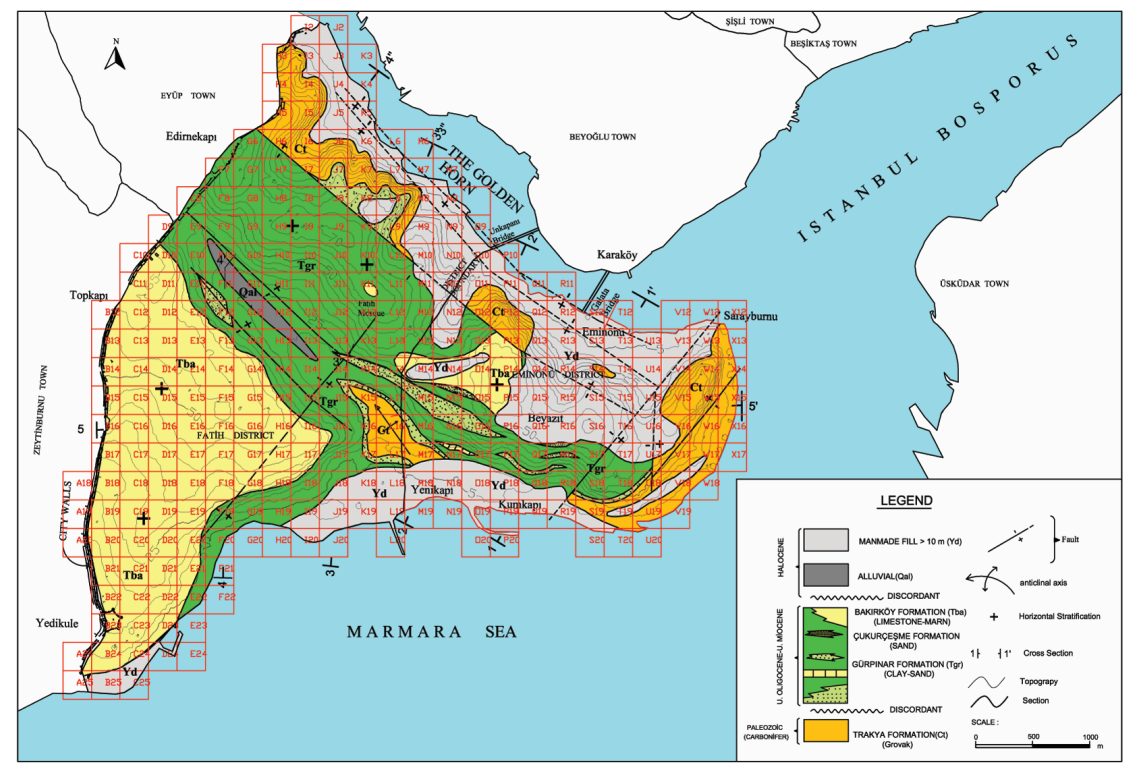

Fig. 6. Engineering Geological Map of the Historical Peninsula (Özaydın et al., 2005).

the change of the shear modulus and damping with the shear strain level.

\subsection{Earthquake input file}

Regional earthquake risk analysis for the study area was performed with respect to the probability of exceedance of $10 \%$ within the scope of the GSHAP (1999) project by Bogazici University and the base rock spectral acceleration parameters were determined using SEISRISK III (Bender and Perkins, 1987). According to the defined spectral acceleration values for each cell, synthetic earthquake motions compatible with National Earthquake Hazards Reduction Programme (NEHRP) acceleration response spectrum are produced with TARCSTHS (Papageorgiou et al., 2000) programme.

\subsection{Soil profile and material parameters}

A representative soil profile was defined for each $250 \mathrm{~m} \times 250 \mathrm{~m}$ cell and for each soil stratum, a shear wave velocity value is assigned and variation of the $G / G_{\max }$ with the strain level relationship was chosen from literature corresponding to the soil type to be used in the EERA (Bardet et al., 2000) as shown in Table 2. For the clayey soils the relationships proposed by Vucetic and Dobry (1991) for the $G / G_{\max }$ and damping relationships taking into consideration soil plasticity were used, whereas for the Cukurcesme and Gürpınar sands the Seed and Idriss (1970) relations and for the Bakirköy Formation limestone those proposed by Idriss (1990) were also used.

\section{Seismic microzonation with respect to ground motion}

In microzoning, with respect to ground shaking intensity, both the spectral accelerations found from site response analysis and the amplification values calculated with the Midorikawa empirical relationships are taken into consideration. The values of the parameters are used in this type of microzonation merely to differentiate three zones with relatively different hazard levels with respect to ground shaking intensity (MERM, 2003). A ground shaking intensity map for the probability of exceedance of $10 \%$ in $50 \mathrm{yr}$, was produced, taking into consideration both the average spectral acceleration values calculated from the site response analysis and spectral amplification values calculated from the equivalent shear wave velocity. Considering the zoning from average spectral acceleration values calculated from the site response analysis $\left(A_{\mathrm{s}}, B_{\mathrm{s}}\right.$ and $C_{\mathrm{s}}$ zones) and spectral amplification values calculated from the equivalent shear wave velocity ( $A_{\mathrm{v}}, B_{\mathrm{v}}$ and $C_{\mathrm{v}}$ zones) according to MERM (2003), the final microzonation maps were prepared (Table 3 ). $A_{\mathrm{GS}}$ corresponds to the high risk zones, $B_{\mathrm{GS}}$ corresponds to the intermediate risk zones and $C_{\mathrm{GS}}$ corresponds to the low risk zones. The resulting map is shown in Fig. 11 along with the damage caused by the 1894 earthquake. Comparing the ground shaking intensity map with the geology map, it can be seen that areas covered with artificial fill and alluvium are mapped as $A_{\mathrm{GS}}$ and $B_{\mathrm{GS}}$ and areas covered with Upper Oligocene-Upper Miocene deposits are mapped $A_{\mathrm{GS}}, B_{\mathrm{GS}}$ and $C_{\mathrm{GS}}$ depending on factors such as distance from fault zone and local soil conditions. 


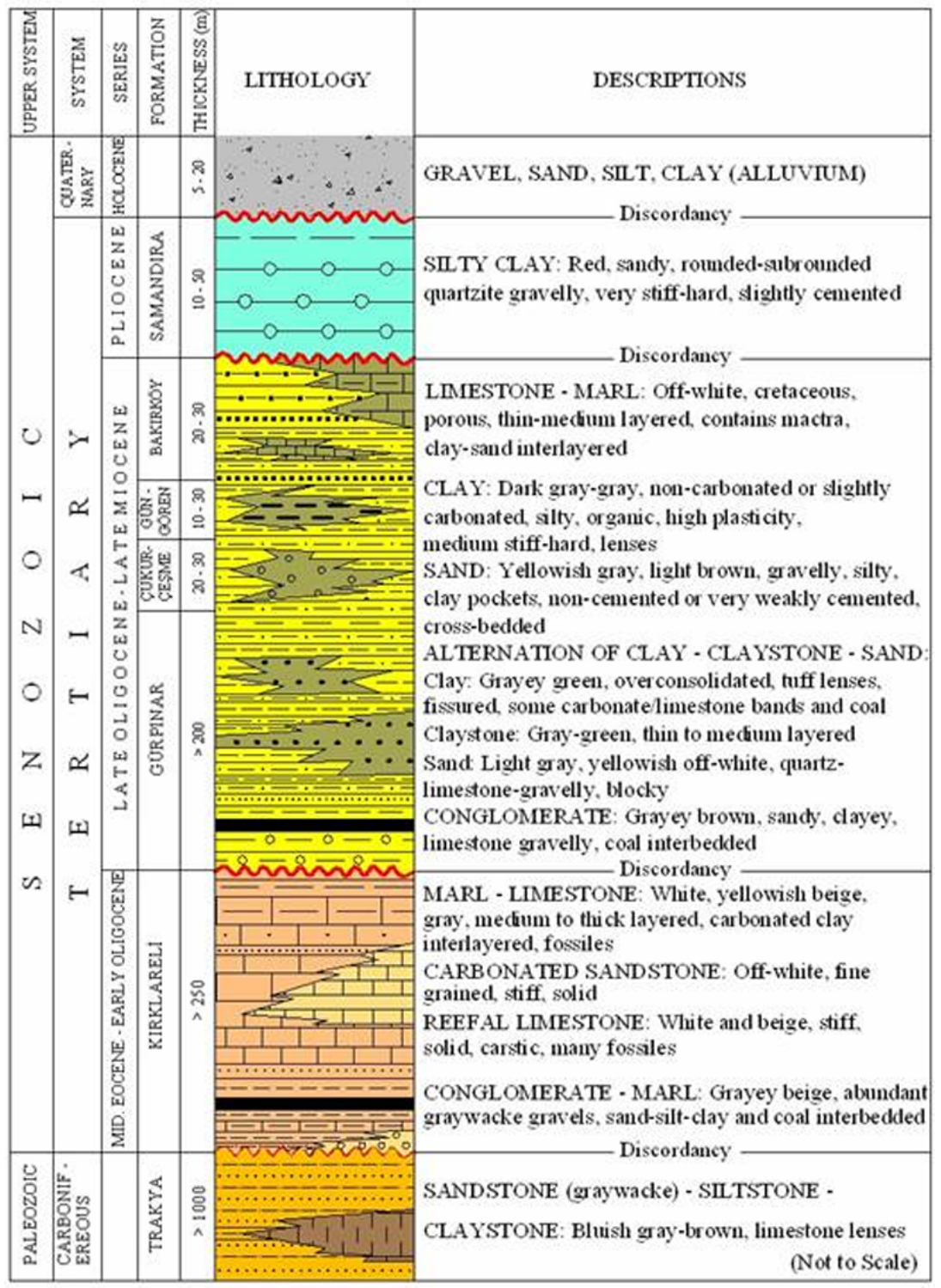

Fig. 7. Stratigraphy of the Tertiary Deposits of Istanbul city and its Vicinity (Yıldırım and Savaşkan, 2003).
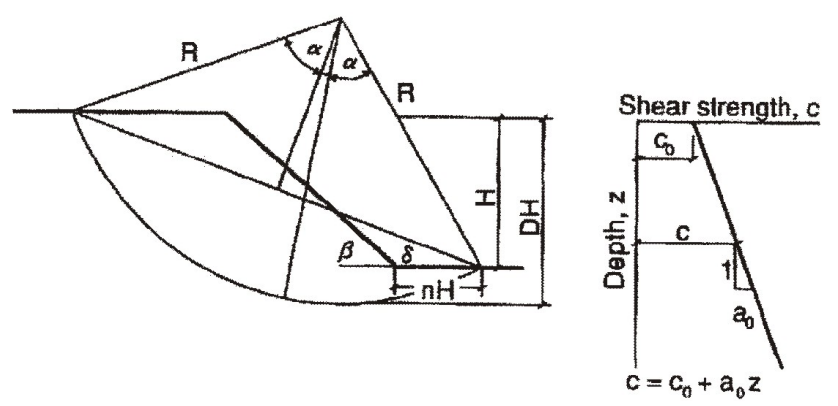

Fig. 8. A typical slope section and slope stability parameters (MERM, 2003).

\section{Microzonation for landslide hazard}

Microzonation studies, with respect to seismic landslide hazard, were carried out using the slope stability analysis technique suggested by Siyahi and Ansal (1993). In this method, the potential failure surface is assumed to be a circular arc and the variation of shear strength, $c$, with depth is assumed to be linear, as shown in Fig. 8 .

The safety factor, $F_{\mathrm{S}}$ against sliding is defined as follows

$$
F_{\mathrm{s}}=\frac{a_{0}}{\gamma} N_{1}=\frac{\gamma \tan \phi}{\gamma} N_{1}=N_{1} \times \tan \phi
$$

where, $a_{0}$ is the slope of the linear variation of the shear strength with depth; $\phi$ is angle of the shear strength; $\gamma$ is the unit weight of the soil; $N_{1}$ is the stability number. The 
Table 2. Strain dependent relationships used in the site response analysis.

\begin{tabular}{|c|c|c|c|}
\hline Formation & $\gamma_{n}\left(\mathrm{kN} \mathrm{m}^{-3}\right)$ & Material & Strain dependent relationships \\
\hline Fill 1 (Alluvial and artificial) & 18 & Mat 1 & $\begin{array}{l}G / G_{\max }: \text { Vucetic and Dobry (1991), Ip }=\% 25 \\
\text { Damping: Vucetic and Dobry (1991), Ip }=\% 25\end{array}$ \\
\hline Fill 2 (The Golden Horn Deposits ) & 18 & Mat 2 & $\begin{array}{l}G / G_{\max } \text { : Vucetic and Dobry (1991), Ip }=\% 30 \\
\text { Damping: Vucetic and Dobry (1991), Ip }=\% 30\end{array}$ \\
\hline Bakırköy clay & 19 & Mat 3 & $\begin{array}{l}G / G_{\max } \text { : Vucetic and Dobry (1991), Ip }=\% 45 \\
\text { Damping: Vucetic and Dobry (1991), Ip }=\% 45\end{array}$ \\
\hline Bakırköy limestone & 24 & Mat 4 & $\begin{array}{l}\text { Attenuation of rock average and damping in } \\
\text { rock Idriss (1990) }\end{array}$ \\
\hline Gürpınar clay & 20 & Mat 5 & $\begin{array}{l}G / G_{\max }: \text { Vucetic and Dobry (1991), Ip }=\% 40 \\
\text { Damping: Vucetic and Dobry (1991), Ip }=\% 40\end{array}$ \\
\hline Çukurçeşme and Gürpınar sand & 20 & Mat 6 & $\begin{array}{l}G / G_{\max }: \text { Seed and Idriss (1970), upper range } \\
\text { Damping: Idriss (1990) }\end{array}$ \\
\hline Gürpınar base (sandy gravel) & 21 & Mat 7 & $\begin{array}{l}G / G_{\max }: \text { Seed and Idriss (1970), upper range } \\
\text { Damping: Seed and Idriss (1970), average }\end{array}$ \\
\hline Trakya Limestone (Bedrock) & 25 & - & - \\
\hline
\end{tabular}

Table 3. The combination of zones used to produce the ground shaking zonation map (MERM, 2003).

\begin{tabular}{ll}
\hline Zone & Combined zones \\
\hline$A_{\mathrm{GS}}$ & Overlapping zones of $A_{\mathrm{S}}$ and $A_{\mathrm{v}}$ or $A_{\mathrm{S}}$ and $B_{\mathrm{V}}$ or $B_{\mathrm{S}}$ and $A_{\mathrm{V}}$ \\
$B_{\mathrm{GS}}$ & Overlapping zones of $A_{\mathrm{S}}$ and $C_{\mathrm{v}}$ or $C_{\mathrm{S}}$ and $A_{\mathrm{v}}$ or $B_{\mathrm{S}}$ and $B_{\mathrm{V}}$ \\
$C_{\mathrm{GS}}$ & Overlapping zones of $B_{\mathrm{S}}$ and $C_{\mathrm{v}}$ or $C_{\mathrm{S}}$ and $B_{\mathrm{V}}$ or $C_{\mathrm{S}}$ and $C_{\mathrm{v}}$ \\
\hline
\end{tabular}

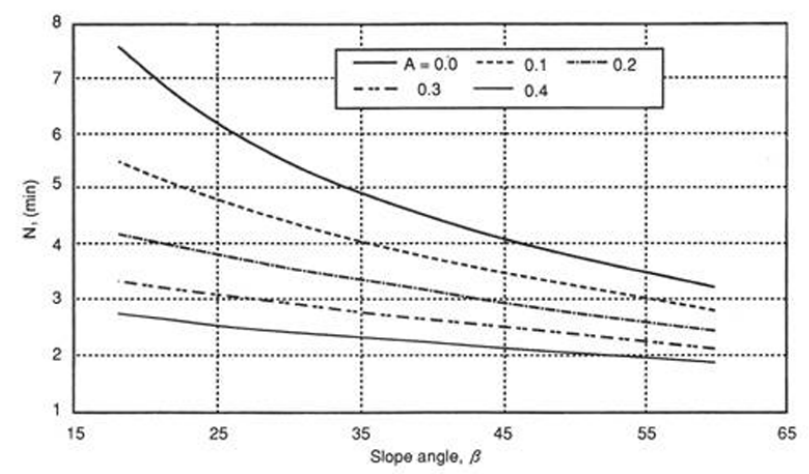

Fig. 9. Minimum N1 stability number change (Siyahi and Ansal, 1993).

graph in Fig. 9 presents the change of the stability number due to the slope angle and peak surface acceleration.

\subsection{Selection of slope stability parameters}

The steepest slope angle in each cell of $250 \mathrm{~m} \times 250 \mathrm{~m}$ was determined from topographical maps and the peak ground surface accelerations were determined from one dimensional site response analysis. The angle of shear strength values used in the slope stability assessment is taken from Yildırım and Savaşkan (2002) as shown in Table 4.

\subsection{Computer programme used for slope stability analysis}

KOERISLOPE V 1.0 programme, developed for seismic slope stability analysis by Fahjan et al. (2003) and based on the methodology proposed by Siyahi and Ansal (1993), was used for seismic slope stability analysis for the assessment of landslide hazard in the study area. It is a Map Basic application with a standard interface which works with a Map Info Programme on a geographic cell system. Input data include slope angle, soil shear strength angle $(\phi)$ and peak ground acceleration (PGA) values determined by the site response analysis. As a result of analysis $N_{1}$, stability number and $F_{\mathrm{S}}$, factor of safety values are determined.

\subsection{Microzonation in relation to landslide hazard}

According to the factor of safety values determined from the seismic slope stability analysis for an earthquake probability exceeding $10 \%$ in $50 \mathrm{yr}$, three zones; $A_{\mathrm{SL}}, B_{\mathrm{SL}}$ and $C_{\mathrm{SL}}$ are defined corresponding to landslide hazard levels. $A_{\mathrm{SL}}$ represents areas where the factor of safety is smaller than one, in $B_{\mathrm{SL}}$, areas the factor is between 1 and 2 , and in $C_{\mathrm{SL}}$ areas, it is larger than 2 . Figure 12 shows the slope stability hazard map with the damage distribution of the 1894 earthquake for the probability of exceedance of $10 \%$. From the map which was obtained, it was determined that the values of the slope angle and peak surface acceleration are effective for the formation of the risk zones and slope failure risk is high in the zones with a slope angle higher than 10 degrees and peak 
Table 4. Residual shear strength angles for major formations considered in the seismic slope stability assessment (Yıldırım and Savaşkan, 2002).

\begin{tabular}{lcc}
\hline Formation & $\begin{array}{c}\gamma_{n} \\
\left(\mathrm{kN} \mathrm{m}^{-3}\right)\end{array}$ & $\begin{array}{c}\text { Residual shear } \\
\text { strength angle } \phi_{f}\end{array}$ \\
\hline Fill 1 (Alluvium and man-made ) & 18 & 20 \\
Fill 2 (The Golden Horn Sediments) & 18 & 18 \\
Bakırköy Clay & 19 & 17 \\
Bakırköy Limestone & 24 & 23 \\
Gürpınar clay & 20 & 20 \\
Çukurçeşme and Gürpınar sand & 20 & 25 \\
Gürpınar base (sandy gravel) & 21 & 25 \\
Trakya Limestone (Bedrock) & 25 & 25 \\
\hline
\end{tabular}

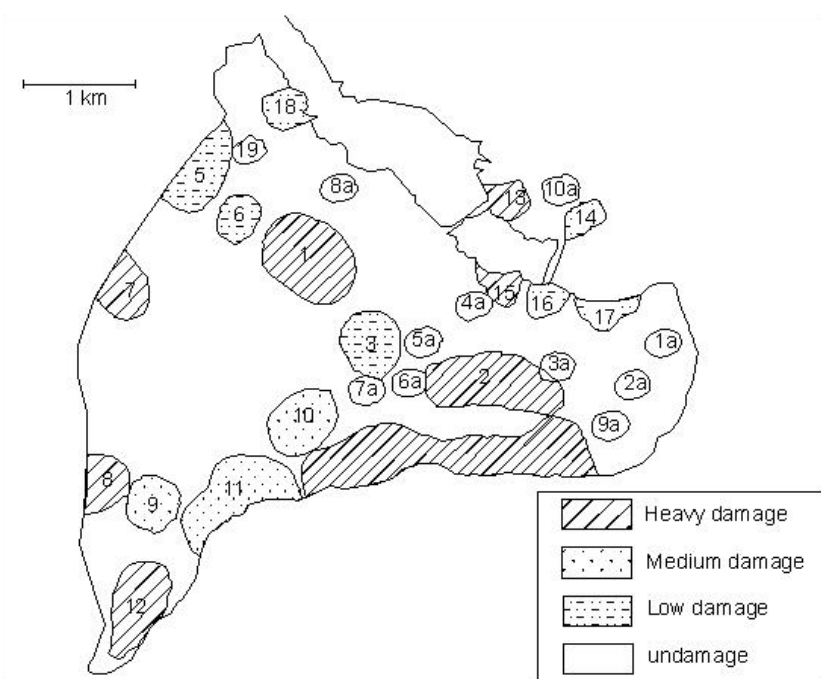

Fig. 10. Regional Damage Map of the 1894 earthquake (Lav, 1994).

surface accelerations between 0.21 and $0.68 \mathrm{~g}$, in accordance with probabilities exceeding $10 \%$ in $50 \mathrm{yr}$. The microzonation map for landslide hazard indicates that landslide hazard during a probable earthquake is quite low and consistent with the geological, morphological and topographical features of the study area.

\section{Liquefaction potential of the region}

In this study, the microzonation map in terms of liquefaction susceptibility, was developed for the areas covered with artificial fill and alluvial deposits in the historical peninsula study area based on the method developed by Youd et al. (2001) and Iwasaki et al. (1982a, b) as recommended in the Microzonation Manual Part 2II (MERM, 2003). This widely accepted procedure is an extended version of the Standard Penetration Test (SPT) based method proposed by Seed et al. (1984, 1985).

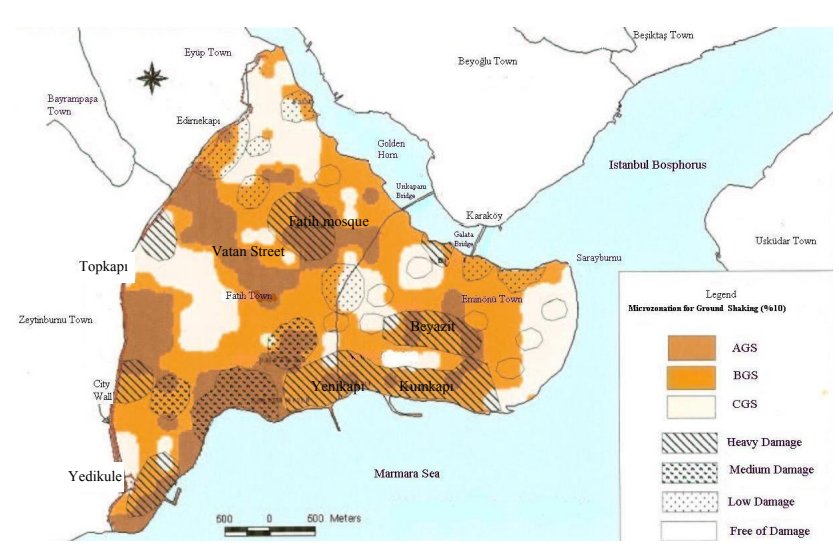

Fig. 11. Comparison of the Regional Damage Map of the 1894 earthquake (Lav, 1994) and the ground-shaking microzonation map prepared for probability of exceedance of $10 \%$ in $50 \mathrm{yr}$ (Ince, 2005).

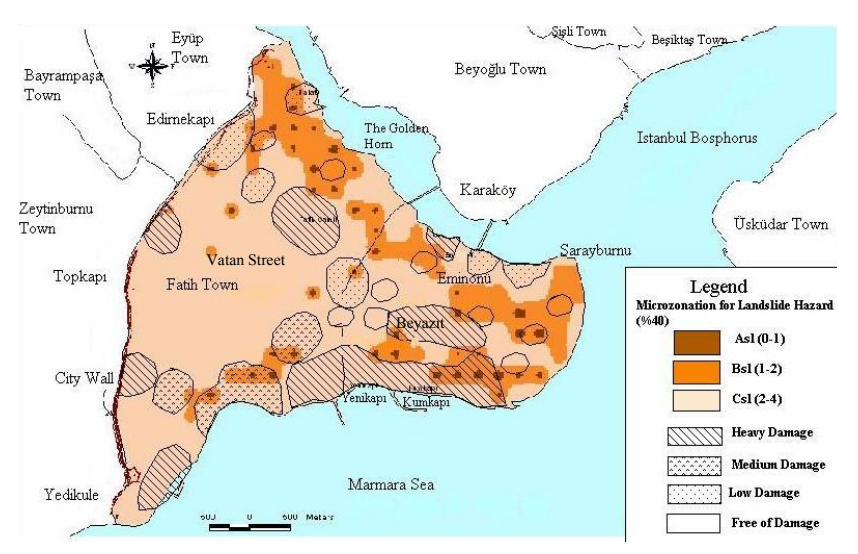

Fig. 12. Comparison of the Regional Damage Map of the 1894 earthquake (Lav, 1994) and landslide hazard microzonation map prepared for the probability of exceedance of $10 \%$ in $50 \mathrm{yr}$ (İnce, 2005).

In the assessment of the study area for liquefaction hazard, areas covered with artificial fill and alluvium such as Vatan Street (Yenibahçe brook) and The Golden Horn coast, as well as Kumkapı and Yenikapı coast line along Marmara Sea were investigated. Other areas which are covered with Bakırköy formation, Gürpınar formation and Thrace formation comprise of soils with low sand and silt content which are free from liquefaction risk. The liquefaction assessment was carried out in 108 cells identified as potential risk areas considering the top $20 \mathrm{~m}$ of the soil profile and the liquefaction potential index was determined for each cell based on the procedure developed by Iwasaki et al. (1982a, b). This procedure predicts the liquefaction performance of the soil profile at a specific site to a depth of $20 \mathrm{~m}$ by employing a 


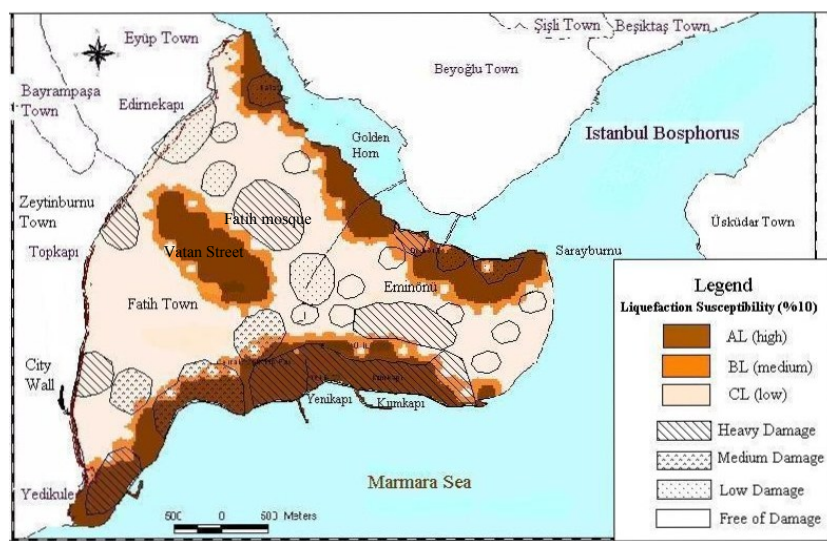

Fig. 13. Comparison of Regional Damage Map of the 1894 earthquake (Lav, 1994) and Liquefaction Susceptibility microzonation map prepared for the probability of exceedance of $10 \%$ in $50 \mathrm{yr}$ (İnce, 2005).

Table 5. Liquefaction potential according to the Liquefaction Potential Index $\left(P_{\mathrm{L}}\right)(\mathrm{MERM}, 2003)$.

\begin{tabular}{ll}
\hline Liquefaction Potential & $P_{\mathrm{L}}$ \\
\hline None & 0 \\
Low & $0<\mathrm{LPI}<5$ \\
Medium & $5<\mathrm{LPI}<15$ \\
High & LPI $>15$ \\
\hline
\end{tabular}

liquefaction potential index, $P_{\mathrm{L}}$ defined as;

$\mathrm{LPI}=\int_{0}^{20} F(z) w(z) d z$

where $z$ is the depth below the ground water surface in metres,

$F_{\mathrm{L}}=1-\mathrm{FS}_{\mathrm{L}} \mathrm{FS} \leq 1$

$F_{\mathrm{L}}=0 \mathrm{FS}>1$

$w_{z}=10-0,5 z$

Table 5 shows the assessment of liquefaction hazard according to Liquefaction Potential Index. For each of the three hazard level zones $A_{\mathrm{L}}, B_{\mathrm{L}}$ and $C_{\mathrm{L}}$ define in the study area, $A_{\mathrm{L}}$ represents areas where $\mathrm{PL}>15, B_{\mathrm{L}}$ where $5>\mathrm{PL}>15$ and where $\mathrm{PL}<5$. Figure 13, combines the liquefaction hazard map and damage distribution map showing that the shores of Marmara Sea and Golden Horn and a narrow band along the Vatan Street are the most susceptible areas for liquefaction in the historical peninsula.

\section{Regional structure damage data from the $\mathbf{1 8 9 4}$ earthquake}

Prior to the Kocaeli earthquake on 17 August 1999, the earthquake in 1894 on 10 July substantially affected the region. The epicentre of the earthquake was located at $40.8^{\circ} \mathrm{N}$ and $29^{\circ} \mathrm{E}$, approximately $60 \mathrm{~km}$ from the study area with an intensity of $\mathrm{X}$ throughout the Marmara region according to the MSK scale. However, there are some ambiguities concerning the intensity values of the iso-intense regions numbered one to four on iso-intense map produced by Eginitis (1894). While the 1894 earthquake was reported as having a 6.7 magnitude and with a VIII intensity in and around Istanbul (Barka, 1991), a group of researchers noted that the intensity was X (Gündoğdu, 1991). Despite this ambiguity concerning the value of intensity, since values are determined with respect to observed damage, they include the effects of local ground conditions as well. In the study area, the damage data relevant to the 1894 earthquake (Lav, 1994) were compiled according to the work of several researchers. The damaged structures were numbered from 1 to 19 according to the level of damage and Table 6 presents a description of the damage to each structure, whereas the damage map is given in Fig. 10.

The definition of the damage in an area were given values ranging from 0 to 1 , these were added and then divided by the damage definition count, resulting in a damage value. The classification of the degree of damage as heavy, moderate and slight was conducted by collocating these values (Lav, 1994). In Fig. 11, the 1894 earthquake damage distribution and the ground shaking prepared for probability of exceedance of $10 \%$ in $50 \mathrm{yr}$ are presented. When this map is evaluated, it is seen that the area containing the Fatih Mosque and the heavily damaged areas in Beyazit are located in the zones of $A_{\mathrm{GS}}$ and $B_{\mathrm{GS}}$ in the ground shaking microzonation map.

In Yenikapı and Kumkapı that are located in the southern coast of the study area, it is again seen that the heavily damaged areas are in $A_{\mathrm{GS}}$ and $B_{\mathrm{GS}}$ zones, but only a few areas are located in $C_{\mathrm{GS}}$ zone. The heavily damaged area near Topkapı is located within $C_{\mathrm{GS}}$ zone and this area is not in accordance with the ground shaking microzonation map. It is seen that the heavy damage that occurred in Yedikule is in $A_{\mathrm{GS}}$ and $B_{\mathrm{GS}}$ zones with very few areas placed in the $C_{\mathrm{GS}}$ zone. The other heavily damaged region in the Fatih district is located in the $A_{\mathrm{GS}}$ and $B_{\mathrm{GS}}$ zones. The heavily damaged area along Eminönü shore is located in the $B_{\mathrm{GS}}$ and $C_{\mathrm{GS}}$ zones in the ground shaking microzonation map. The areas which were moderately damaged in the 1894 earthquake within the boundaries of the Fatih district and these regions are in $A_{\mathrm{GS}}$ and $B_{\mathrm{GS}}$ zones in the ground shaking microzonation map. In the study area, slightly damaged areas can be seen in all the $A_{\mathrm{GS}}, B_{\mathrm{GS}}, C_{\mathrm{GS}}$ zones.

In Fig. 12, the distribution of the damage caused by the 1894 earthquake is presented with the landslide hazard map 
Table 6. Building damage reports from the 1894 earthquake (Lav, 1994).

1 The domes and walls of Bali Paşa Mosque in Fatih collapsed. The caravanserais and mosques in Fatih and he walls of Darüşşafaka collapsed.

2 The dome and walls of a public bath in Laleli and a large part of the Vezirhan in Çemberlitaş collapsed. Part of the Grand Bazaar collapsed and large part was completely ruined. The public baths around the Grand Bazaar were ruined, Süleyman Paşa Public Bath in Divanyolu was completely demolished. Many places in the Chicken Bazaar were demolished and the Yemenciler Bazaar was completely demolished. Some caravanserai in the Grand Bazaar collapsed and caravanserai in Beyazit was completely demolished. In Koska the top part of the minaret of the Papazoğlu Mosque and the roof of the Papazoğlu Mosque madrasa in Koska collapsed. The minaret of the Uzun Şücaaddin Mosque in Sultanahmet Peykhane was demolished.

3 The top parts of the minarets of the Mimar Ayas Mosque and the Dülgeroğlu Mosque both in Saraçhanebaşı collapsed. The domes of some rooms in the Amcazade Madrasa also collapsed, the school was partially demolished.

4 Many houses in Gedikpaşa, Kadırga, Kumkapı, Yenikapı, Langa collapsed and in Samatya many houses and shops were demolished.

5 The minaret of the Mihrimah Sultan Mosque in Edirnekapı collapsed, The Edirnekapı ramparts fell down. The door of the Mihrimah Sultan Public Bath in Edirnekapı was demolished and half of the Kariye Mosque collapsed.

6 The minaret of the Karagümrük Mosque collapsed.

7 The Ahmet Paşa Mosque in Topkapı was ruined.

8 The mescid and Islamic monastery in Silivrikapı were devastated.

9 The dome of the Koca Mustafa Paşa Mosque collapsed.

10 The dome of the Haseki Sultan Mosque in Haseki collapsed, The furnace of the Horhor Public Bath was demolished.

11 Some of the domes of the Cerrah Paşa Mosque collapsed.

12 The Abid Çelebi Mosque and its monastery were demolished, the İmrahor Mosque was devastated and closed for many years.

13 The Sokulu Mehmet Paşa Mosque in Azapkapı was demolished and remained closed for a long time.

14 The minaret of the Yeraltı Mosque in Galata partially collapsed.

15 The Hacı Mustafa Paşa Mosque in Zindankapı was demolished, The Ahi çelebi Mosque in Zindankapı was ruined, the Uzun Çarşı, Tahtakale, Kutucular, and Kantarcılar were completely devastated.

16 The furnace of the Yeni Mosque was demolished and the minaret of the İzzet Mehmet Paşa Mosque in Eminönü collapsed.

17 The minaret of the mosque around İstasyon in Sirkeci completely collapsed and there was a $42 \mathrm{~m}$ long crack in the ground in front of Sirkeci seaport.

18 Trees were uprooted in Balat.

19 The minaret of the Hoca Kasim Mosque in Draman was demolished.

for the probability of exceedance of $\% 10$ in $50 \mathrm{yr}$. In general, it can be said that the area does not carry a large risk according to the slope stability hazard and, when assessed together with the regional damage map, it has no effect on the earthquake damage. However, more detailed studies should be conducted in certain zones which are known to be at risk according to slope stability. In Fig. 13, the liquefaction hazard map and damage distribution map have been combined for the probability of exceedance of $10 \%$ in $50 \mathrm{yr}$. Along the Yenikap1 and Kumkapı coastline and around Yedikule where the hazard of liquefaction is high, severe damage was observed. The severely damaged region in the part of the Eminönü district on the Golden Horn coast is placed in the
$A_{\mathrm{L}}$ and $B_{\mathrm{L}}$ regions on the liquefaction hazard map. Except for the part of the Fatih district that is on the coast throughout the areas with high risk of liquefaction, generally there was no severe to mild damage. Of the weakly damaged areas, those on the Golden Horn coastline were located in $A_{\mathrm{L}}$ and $B_{\mathrm{L}}$ regions, whereas the other weakly damaged areas were located in the $C_{\mathrm{L}}$ region which has low risk potential in terms of liquefaction. In the study area, it was observed that the liquefaction might have had an effect on the level of damage in the 1894 earthquake throughout the Marmara Sea region and on the Golden Horn coast. However, around Vatan Street where there was a liquefaction hazard, no damage occurred. 
Table 7. The construction dates of the historical structures in Old Istanbul (Fatih-Eminönü districts) and their damage levels during several earthquakes (Erdik et al., 2001).

\begin{tabular}{|c|c|c|c|c|c|c|c|c|}
\hline \multirow[b]{2}{*}{ Historical Building Name } & \multirow[b]{2}{*}{$\begin{array}{l}\text { Year of } \\
\text { Construction }\end{array}$} & \multicolumn{7}{|c|}{ Historical Earthquakes } \\
\hline & & $\begin{array}{l}10.09 .1509 \\
(7.6)\end{array}$ & $\begin{array}{l}10.05 .1556 \\
\mathrm{r}(7.0)\end{array}$ & $\begin{array}{l}25.05 .1719 \\
(7.6)\end{array}$ & $\begin{array}{l}02.09 .1754 \\
\quad(7.0)\end{array}$ & $\begin{array}{l}22.05 .1766 \\
(7.2)\end{array}$ & $\begin{array}{l}10.07 .1894 \\
\quad(7.0)\end{array}$ & $\begin{array}{c}17.08 .1999 \\
(7.4)\end{array}$ \\
\hline Ayasofya & 360 & 3 & 2 & 2 & 3 & 2 & 1 & 0 \\
\hline Bali Pasha Mosque & 1504 & 0 & 0 & 3 & 0 & 4 & 4 & 0 \\
\hline Beyazıt Mosque & 1506 & 4 & 0 & 2 & 2 & 3 & 3 & 0 \\
\hline Davut Pasha Mosque & 1485 & 4 & 0 & 0 & 0 & 4 & 3 & 0 \\
\hline Fatih Mosque & $1463-1470$ & 3 & 3 & 2 & 3 & 4 & 3 & 1 \\
\hline Mihrimah Sultan Mosque & $\begin{array}{l}\text { 16th century } \\
\text { (at the end of the century) }\end{array}$ & 0 & 0 & 2 & 0 & 3 & 4 & 2 \\
\hline Nur-u Osmaniye Mosque & 1755 & 0 & 0 & 0 & 0 & 2 & 2 & 0 \\
\hline Sultan Ahmet Mosque & $1609-1616$ & 0 & 0 & 0 & 0 & 3 & 4 & 0 \\
\hline Sultan Selim Mosque & 1522 & 0 & 0 & 0 & 0 & 2 & 3 & 0 \\
\hline Süleymaniye Mosque & $1550-1557$ & 0 & 0 & 0 & 0 & 2 & 2 & 0 \\
\hline Şekerciler Caravanserai & - & 0 & 0 & 0 & 4 & 4 & 4 & 0 \\
\hline Topkapı Palace & $1461-1468$ & 2 & 0 & 0 & 3 & 3 & 2 & 1 \\
\hline Valide Public house & - & 0 & 0 & 0 & 0 & 3 & 4 & 0 \\
\hline Valide Mosque & 1871 & 0 & 0 & 0 & 0 & 2 & 2 & 0 \\
\hline \multirow[t]{2}{*}{ Vizier Public House } & 1661 & 0 & 0 & 0 & 3 & 4 & 5 & 0 \\
\hline & & \multicolumn{7}{|c|}{ Damage Levels } \\
\hline
\end{tabular}

Generally, areas which were severely damaged are located in the high risk regions on the liquefaction maps and, in terms of geological formation, they are seen in regions with thick clay layers (Gürpınar formation) and around the Marmara Sea coastline where thick fillings are present and where Bakırköy formation has surfaced.

The areas of mild damage are located where the Gürpınar formation and certain regions of Bakırköy formation exist. In some regions along the Golden Horn coastline where there are thick fillings and in Edirnekapı where thick clay layers (Gürpınar formation) only slight damage occurred and in areas where the Trakya formation surfaces there was no damage. Overall, the damage distribution and liquefaction risk map and geology maps are in accordance except for some regions. Throughout the region local ground conditions and liquefaction generally affect the level of damage following an earthquake.

When the 1894 damage map in Fig. 10 and the ground shaking map in Fig. 11 are compared, the area where there was a high level of damage is labelled as Zone 1 and contains the risk areas $A_{\mathrm{GS}}$ and $B_{\mathrm{GS}}$, and Zone 3 contains the $C_{\mathrm{GS}}$ area which is relatively less risk. However, in parts of zones 2 and 3 that lie within the boundaries of Fatih district the damage levels are not in accordance with the earthquake maps.

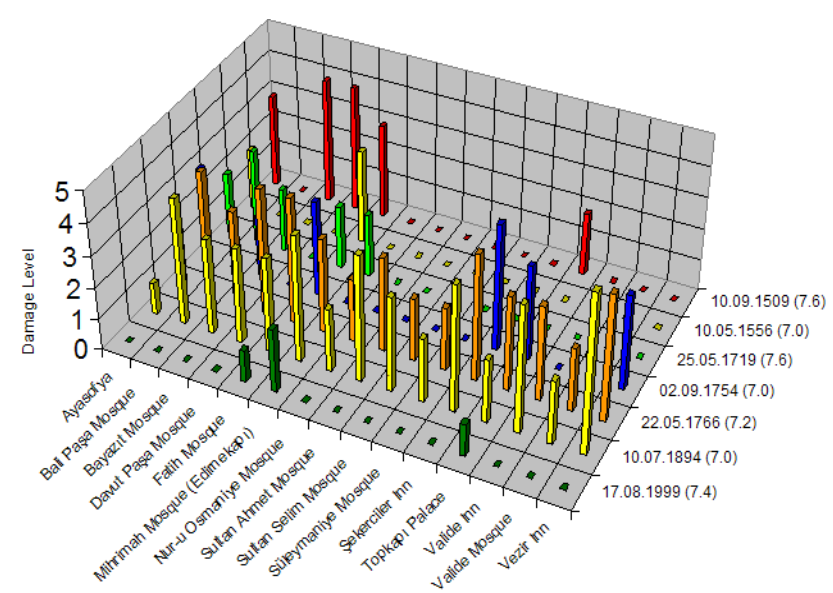

Fig. 14. Earthquake damage in historical structures in Old İstanbul area 1 (Fatih-Eminönü districts) (Erdik et al., 2001)

\section{Details of the damage to significant historical structures in the study area}

The study area of the Fatih and Eminonu district is historically rich containing the following important buildings; Santa Sophia, Topkapı Palace, Beyazıt Mosque, Fatih Mosque, Nur-u Osmaniye Mosque, Sultan Ahmet Mosque, Süleymaniye Mosque, Mihrimah Sultan Mosque, Şekerciler Caravanserai, Valide Caravanserai, Valide Mosque, Bali Paşa Mosque and the Vezir Caravanserai. Information about the 


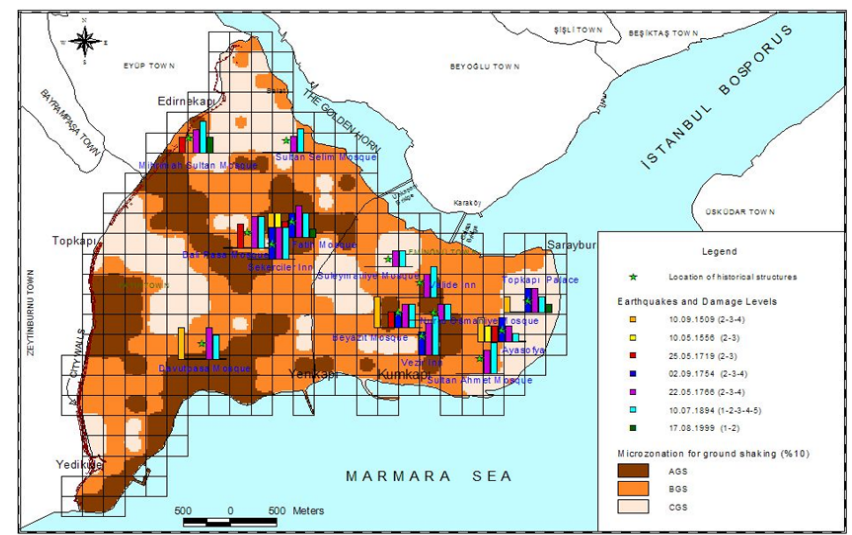

Fig. 15. Comparison of damage levels in various earthquakes and Ground shaking microzonation map prepared for probability of exceedance of $10 \%$ in $50 \mathrm{yr}$. (İnce, 2005)

damage caused to various historical structures from different earthquakes was evaluated by Erdik et al. (2001). In this study, the damage to these structures during earthquakes is illustrated via a three dimensional matrix shown in Fig. 14 and Table 7 that gives the date of construction and the level of damage related to seven earthquakes from 1509 to 1999. In line with the European macro seismic scale (ESM, 1998) the damage is defined by the codes, D1, D2, D3, D4 and D5, which indicate slight, moderate, severe, very severe damage and collapse, respectively. This study reveals that Fatih and Edirnekap1 Mihrimah Sultan Mosques are adversely affected by all the earthquakes listed. Information on the damage on historical structures has been evaluated on earthquake micro zoning maps by being displayed on the ArcView 3.1 programme (İnce, 2005).

In Fig. 15, the damage to the historical structures is shown on the earthquake map which is prepared for probability of exceedance of $10 \%$ in $50 \mathrm{yr}$. It is seen that the zone (including Fatih Mosque) which was damaged in all earthquakes is found in the $A_{\mathrm{GS}}$ area of highest risk on the earthquake map. Furthermore, on the geology maps this zone is placed in the area with thick clay ground (55-60 m). Similarly, the Davut Paşa, Beyazıt, and Nur-u Osmaniye Mosques are in the $A_{\mathrm{GS}}$ zone in the earthquake map. Bali Paşa Mosque, Şekerciler Hanı, Vezir Hanı, Sultan Ahmet Mosque, and Ayasofya Mosque are found in the $B_{\mathrm{GS}}$ zones in the earthquake map. Although the Sultan Selim Mosque, Süleymaniye Mosque and Topkap1 Palace are in the $C_{\mathrm{GS}}$ zone, small to medium level damage was observed in these areas in some of the earthquakes.

When the damage to the historical structures was assessed together with the landslide hazard map (Fig. 16), it is seen that the Davut Paşa, Beyazıt, and Nur-u Osmaniye Mosques are in the $B_{\mathrm{sl}}$ zone which presents medium level risk due to the slope. The other mosques in the study area are in the nonrisk zones determined in terms of landslide hazard. Having

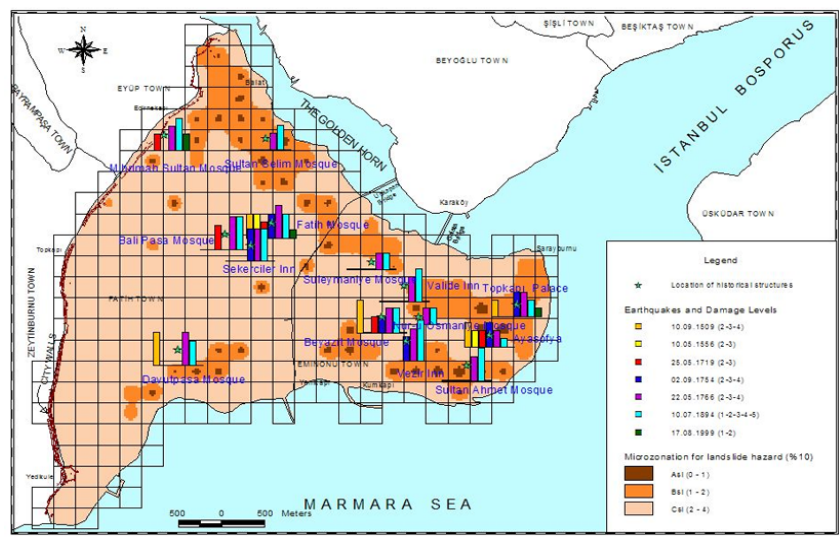

Fig. 16. Comparison of damage levels in various earthquakes and the landslide hazard microzonation map prepared for probability of exceedance of $10 \%$ in $50 \mathrm{yr}$ (İnce, 2005).

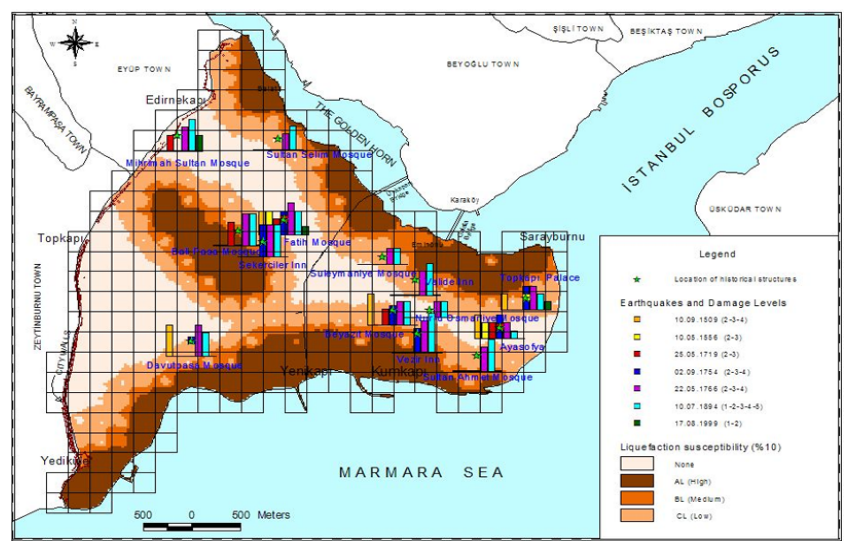

Fig. 17. Comparison of damage levels in various earthquakes and the liquefaction hazard microzonation map prepared for probability of exceedance of $10 \%$ in $50 \mathrm{yr}$ (İnce, 2005).

compared the damage to historical structures with the liquefaction map (Fig. 17) it emerges that the mosques are located in general within regions which have no or minimum risk of liquefaction.

Generally it can be said that, ground motion amplification, an impact generated from ground conditions is related to the extent of damage to the historical structures. Increasing levels of damage was observed in the thick clay layers which have the property of enlarging the earthquake motion, in the filling layers, and in some areas with Bakırköy formations. According to the slope failure hazard, it is thought that the slope motions might have had an effect on the earthquake damage in the past in some limited areas of the research zone. 


\section{Conclusions}

In this study, the damage to historical structures in the Fatih and Eminonu districts caused by the major earthquake in 1894 in Istanbul was assessed using damage records and the seismic micro zoning maps.

Generally the damage in the Marmara region and the micro zoning maps corresponded with each other and the damage was confined to the $A_{\mathrm{GS}}$ and $B_{\mathrm{GS}}$ zones of the earthquake intensity maps which are denoted as high risk and medium risk zones, respectively. When the damage records of the historical structures in the study area were examined, it was found that except for a few mosques, the damage was confined to the $A_{\mathrm{GS}}$ and $B_{\mathrm{GS}}$ zones. It was observed from the geological maps, that the areas containing damage are the zones with thick clay layers and fillings. The region does not include much risk due to the slope stability, therefore, it does not have much effect on the damage. The liquefaction risk is seen on the Vatan Street which follows the route of an older river bed, in the Kumkapı and Yenikapı and The Golden Horn coastlines. When the damage maps and liquefaction risk map are compared, it appears that liquefaction might have had an effect on the extent of the damage in some areas. Finally, it is seen that the damage observed in the area generally corresponds to the micro zoning maps and the ground motion amplification, and partial liquefaction does contribute to the damage incurred as a result of the 1894 earthquake.

Acknowledgements. The author would like to thank İ. Kutay Özaydın, Mustafa Yıldırım and Pelin Tohumcu Özener.

Edited by: M. E. Contadakis

Reviewed by: A. P. D. Reis and G. Karakaisis

\section{References}

Bardet, J. P., Ichii, K., and Lin, C. H.: EERA: A computer programme for equivalent-linear earthquake site response analyses of layered soil deposits, University of Southern California, Los Angeles, 2000.

Barka, A.: Tectonic Structures Creating the Seismicity of Istanbul and An Experimental Micro-zoning for Istanbul, Istanbul Earthquake Symposium, IMO Istanbul Branch, 35-36, 1991.

Baykal, A. F.: Historic geology, İstanbul Üniversity, Faculty of Science publications, 127, 403 pp., 1974 (in Turkish).

Bender, B. and Perkins, D. M.: SEISRISK III: A Computer Program for Seismic Hazard Estimation, USGS Bulletin 1772, US Government Printing Office, Washington, 1987.

Chang, K. P. and Chang, T. S.: Liquefaction induced earth movements and mitigation in an Earthquake-Prone area, in: Developments in geotechnical engineering: From Harvard to New Delhi, 1936-1994: Proceedings: Symposium on Developments in Geotechnical Engineering (1994: Bangkok, Thailand), edited by: Balasubramaniam, A. S., Bergado, D. T., Hong, S. W., Nutalaya, P., ISBN 9054105224, 291-299, 1994.

Eginitis, M. D.: Earthquake Report, Prime Minister's Archive, No: 626, 1894 (in the Ottoman Turkish language).
Erdik, M., Durukal, E., Albay, Y., and Birgören, G.: The Concrete Proposal for Seismic Risk and Risk Reduction for Buildings in Istanbul, Chamber of Civil Engineers, Vol: 52, Istanbul, 2001 (in Turkish).

Fahjan, Y. M., Siyahi, B. G., and Ansal, A.: KoeriSlope V1.0: Slope Stability Calculations Software for Micro-zoning Purposes, Bogazici University, Department of Earthquake Engineering, Kandilli, Istanbul, 2003 (in Turkish).

Gündoğdu, O., Altınok, Y., Özer, N., and Kolçak, D.: Earthquake in 1894 and Istanbul, Turkey, Proceedings of 12th General Assembly of Geophysics, 41, 1991 (in Turkish).

Global Seismic Hazard Assessment Programme (GSHAP): available at: http://www.seismo.ethz.ch/static/GSHAP/ (last access: 11 March 2011), 1999.

Idriss, I. M.: Response of soft soil sites during earthquakes, Proceedings of the Symposium to Honor Professor Harry Bolton Seed, Berkeley California, II, 273-289, 1990

İnce, G. Ç.: Seismic Zonation and Earthquake Damage Prediction for Istanbul, Y1ldız Technical University, Ph.D. Thesis, İstanbul, 2005 (in Turkish).

Iwasaki, T., Tatsuoka, F., Tokida, K., and Yasuda, S.: Microzonation of soil liquefaction potential using simplified methods, Proc. 3rd Int. Conf. on microzonation, Seattle, 3, 1319-1330, 1982a.

Iwasaki, T., Tokida, K., Tatsuoka, F., Watanabe, S., Yasuda, S., and Sato, H.: A Practical Method for Assessing Soil Liquefaction Potential Based on Case Studies at Various Sites in Japan, Proc. 2nd. Int. Conf. On Microzonation, San Francisco, Vol. 2, 885896, $1982 b$.

Istanbul Provincial Disaster and Emergency Directorate: Governorship of İstanbul İstanbul Earthquake Symposium, Publication of Chamber of Civil Engineers, 1991 (in Turkish).

Japan International Cooperation Agency (JICA and IMM): The Study on A Disaster Prevention/Mitigation Basic Plan in Istanbul Including Seismic Microzonation in the Republic of Turkey, Main Report, İstanbul, Turkey, 2002.

Kaya, O.: The Carboniferous Stratigraphy of Istanbul, TJK Bulletin, 14/2, 143-201, 1971 (in Turkish).

Lav, A.: Micro-zoning in the Cities of Istanbul and Erzincan in Terms of Soil Augmentation Effects, Istanbul Technical University, Doctoral Thesis, Istanbul, 1994 (in Turkish).

Microzonation for Earthquake Risk Mitigation (MERM): Microzonation Manual, World Institute for Disaster Risk Management, 2003.

Midorikawa, S.: Prediction of isoseismal map in the Kanto plain due to hypothetical earthquake, J. Struct. Eng.-ASCE, 33b, 4348, 1987 (in Japanese with English Abstract).

National Earthquake Hazards Reduction Program (NEHRP): Recommended Provisions for Seismic Regulations for New Buildings and Other Structures, FEMA-303, Prepared by the Building Seismic Safety Council for the Federal Emergency Management Agency, Washington, DC, 1997.

Özaydın, K., İnce, G. Ç., and Yıldırım, M.: Seismic Micro-zoning and Geological-Geotechnical Structure of the Historical Peninsula (Istanbul), 3rd Istanbul and Earthquake Symposium, June 9th-10th, 2005, TMMOB Chamber of Civil Engineers, Istanbul Branch, 181-211, Istanbul, 2005 (in Turkish),

Öztin, F. and Bayülke, N.: Historical Earthquakes in Istanbul, Kayseri and Elazig, Earthquake Research Institute Report, Ankara, Turkey, 22 pp., 1990 (in Turkish). 
Papageorgiou, A., Halldorsson, B., and Dong, G.: TARSCHTS: Target acceleration spectra compatible time histories, University of Buffalo, Dept. of Civil, Structural and Environmental Engrg., NY, 2000.

Regulations on Buildings Constructed in Disaster Areas, (TDY), IMO Press, İzmir Branch, Publication No. 25, 1998.

Sayar, C.: The Geology of the Golden Horn (Haliç) and Surrounding Region. Bosphorus University, National Symposium on the Golden Horn S., 355-374, 1976.

Schnabel, P. B., Lysmer, J., and Seed, H. B.: SHAKE - A Computer Programme for Earthquake Response Analysis of Horizontal Layered Sites, Report No. EERC 72-12, University of California, Berkeley, 88 pp., 1972.

Seed, H. B. and İdriss, I. M.: Influence of soil conditions on ground motions during earthquakes, Journal of the Soil Mechanics and Foundation Division, ASCE, 95, SM1, 99-137, 1969.

Seed, H. B. and İdriss, I. M.: Soil Moduli and Damping Factors for Dynamic Response Analyses, Report No: EERC 70-10, EERC, University of California, Berkley, California, 1970.

Seed, H. B., Tokimatsu, K., Harder, L. F., and Chung, R. M.: Influence of SPT procedures in soil liquefaction resistance evaluations, Earthquake Engineering Research Center Report No. UCB/EERC-84/15, University of California at Berkeley, 1984.

Seed, H. B., Tokimatsu, K., Harder, L. F., and Chung, R. M.: Influence of SPT procedures in soil liquefaction resistance evaluations, J. Geotech. Eng.-ASCE, 111(12), 1425-1445, 1985.

Seed, H. B., Whitman, R. V., Dezfulian, H., Dobry, R., and Idriss, I. M.: Soil conditions and building damage in Caracas earthquake, Journal of the Soil Mechanics and Foundation Division, ASCE, 98, SM8, 787-806, 1972.
Siyahi, B. G. and Ansal, A. M.: Microzonation for slope failures during earthquakes, Proc. of 2nd Turkish National Earthquake Engineering Conf., available at: http://www.tarihimiz. net/v3/haberler/genel/tarihte-istanbul-depremleri.html 563-572, 1993 (in Turkish).

Vardar, M. and Bayraktar, H.: In-Situ Resistance and ITU-MJKM Classification in the Case of Research Gallery of Istanbul Metro, the Bulletin of Turkish National Committee of International Engineering of Geology, Istanbul, 13(28), 14 pp., 1993 (in Turkish).

Vucetic, M. and Dobry, R.: Effect of soil plasticity on cyclic response, American society of Civil Engineering, J. Geotech. Eng.ASCE, 117, 89-107, 1991.

Yıldırım, M. and Savaşkan, E.: The Stratigraphy of the Tertiary Sediments in Istanbul and Their Engineering Properties, the Bulletin of Turkish National Committee of International Engineering of Geology (TNCIEG), 25th Anniversary, Istanbul, 28, 48-62, 2002 (in Turkish).

Yıldırım, M. and Savaşkan, E.: A New Approach to the Stratigraphy of the Tertiary Sediments in Istanbul and Their Engineering Properties, Geology of Istanbul Symposium, Proceedings, TMMOB Chamber of Civil Engineers, Istanbul Branch, Location: Kadir Has University Conference Halls, Cibali, Istanbul, 87-102, 2003 (in Turkish)

Youd, T. L., Idriss, I. M., Andrus, R. D., Arango, I., Castro, G., Christian, C. D., Dobry, R., Finn, W. D. L., Harde Jr., L. F., Hynes, M. E., Ishihara, K., Koester, J. P., Liao, S. S. C., Marcuson III., W. F., Martin, G. R., Mitchell, J. K., Moriwaki, Y., Power, M. S., Robertson, P. K., Seed, R. B., and Stokoe II., K. H.: Liquefaction Resistance of Soils: Summary Report from the 1996 NCEER and 1998 NCEER/NSF Workshops on Evaluation of Liquefaction Resistance of Soils, J. Geotech. Eng.-ASCE, 10(127), 817-833, 2001. 